\section{Валерій КОНОНЕНКО}

\section{Конвенційна безпека як частина правової безпеки держави (на прикладі Будапештського меморандуму)}

\begin{abstract}
Правова безпека держави є станом, в якому вона має можливість правовими засобами забезпечити визнання своїх прав та зобов'язань інших суб'єктів щодо неї, усунути їх порушення і з допомогою міжнародно-правових механізмів відновити стан, який існував до такого порушення.

Досягнення цього стану повинно забезпечуватись системою міжнародно-правових норм, що встановлюють баланс інтересів держави і міжнародного співтовариства. Зокрема, міжнародними договорами, в яких чітко і конкретно прописані зобов'язання сторін та спосіб їх виконання, що не можуть протирічити інтересам держави, механізми вирішення спорів та процедури відновлення порушених прав.

Ключові слова: правова безпека, конвенційна безпека, Будапештський меморандум

The legal security of the state is a state. In this state, it has the opportunity by legal means to ensure the recognition of its rights and obligations of other entities to it. And also to eliminate their violations and with the help of international legal mechanisms to restore the state that existed before such a violation.

Achieving this state must be ensured by a system of international law. These norms establish a balance of interests of the state and the international community. In particular, international agreements, which clearly and specifically specify the obligations of the parties and the manner of their implementation. As well as dispute resolution mechanisms and procedures for restoring violated rights. They can not contradict the interests of the state.
\end{abstract}

Keywords: legal security, conventional security, Budapest Memorandum

Міжнародне право - це система юридичних норм, регулюючих відносини між державами й іншими суб“єктами міжнародного права, які створюються шляхом узгодження позицій учасників цих відносин і забезпечуються у разі потреби індивідуальним або колективним примусом [1, с. 19]. Сдиний спосіб, за допомогою якого створюються міжнародно-правові норми, - це узгодження позицій між суб‘єктами міжнародного права щодо правила поведінки і надання йому юридично обов'язкового характеру [1, с. 84]. Воля і позиція держави пов'язані між собою, але не тотожні. Позиція держави - це вироблені нею умови, які повинні забезпечити баланс інтересів держави і міжнародного співтовариства в процесі вирішення певних міжнародних (і внутрішніх) проблем, а воля спрямована на абсолютний захист ії інтересів. I від того, на скільки держава змогла захистити, «продавити», забезпечити гарантіями свої інтереси, залежить ії правова безпека.

Проблему міжнародно-правових гарантій висвітлювали В. Г. Буткевич, А. М. Талалаєв, О. І. Тіунов, Т. В. Чехович, окремим питанням цієї проблематики присвячені праці М. О. Баймуратова, В. Н. Денисова, С. В. Кульчицького, Л. Д. Тимченка, С. В. Толстова, М. Ю. Черкеса.

Питанням правової безпеки приділяли увагу А. Сзеров, Ю. Ірха, А. Лобода, Г. Арутунян, I. Шинкарьов М. Ентин., О. Ентина, О. Торкунова.

Правову природу Будапештського меморандуму досліджували Ю. Р. Асірян, О. Крисенко, О. Святун, М. Стешенко, І. Лоссовський, В. Гусаров та інші.

Завдання статті: доведення наявності проблеми невідповідності деяких міжнародних договорів інтересам держави, надання визначення категорії «правова безпека держави», встановити засоби досягнення такої безпеки.

УДК 341.6

https://doi.org/10.36952/uail.2020.4.68-73 (C) В. Кононенко

\section{КОНОНЕНКО Валерій}

д.ю.н., доцент кафедри міжнародних відносин, міжнародної інформації та безпеки Харківського національного університету імені В. Н. Каразіна 
Кожна держава на міжнародній арені прагне насамперед захистити і забезпечити свої національні інтереси, не допустити зазіхання на свій суверенітет і міжнародну правосуб‘єктність. До прийняття в 1928 р. Паризького договору про відмову від війни як знаряддя національної політики (Пакту Бріана-Келлога) будь-які засоби, у тому числі і військові, визнавалися правомірними для забезпечення національних інтересів держав у міжнародній системі. Людство до кінця 20 - початку 21 ст. досягло усвідомлення того факту, що безпека стає загальною за своїм характером і може бути забезпечена переважно не воєнними, а політичними й правовими засобами [1, с. 297]. Але у некоректно застосованих правових засобах також криється загроза безпеці держави, більш того, за наявності вразливих місць, вони можуть і спровокувати такі загрози.

Відповідно до ст. 1 Закону України «Про національну безпеку України» державна безпека - це захищеність державного суверенітету, територіальної цілісності і демократичного конституційного ладу та інших життєво важливих національних інтересів від реальних і потенційних загроз невоєнного характеру. А національні інтереси України - це життєво важливі інтереси людини, суспільства і держави, реалізація яких забезпечує державний суверенітет України, ії прогресивний демократичний розвиток, а також безпечні умови життєдіяльності і добробут їі громадян [2]. Але, на жаль, ані в Законі, ані в новій Стратегії національної безпеки України, затвердженій Указом Президента України від 14.09.2020 р. № 392/2020, відсутнє таке поняття, як правова безпека держави.

Г. Арутунян розглядає правову безпеку держави як стан правової захищеності (забезпеченості, гарантованості) життєво важливих інтересів суб'єктів права (індивід, держава, суспільство), можливість відновлення порушених прав та інтересів, а також протидії правовими засобами, які мають об'єктивний і суб'єктивний характер, зовнішнім і внутрішнім загрозам. Він виокремлює як зовнішні, так і внутрішні загрози правовій безпеці держави. До зовнішніх загроз правовій безпеці держави належать: 1) усі можливі міжнародні правові заходи (у тому числі прийняття на міжнародному або регіональному рівнях двосторонніх чи багатосторонніх документів), внаслідок яких може виникнути загроза суверенітету держави та які можуть суперечити Конституції; 2) недостатній правовий захист інтересів держави в міжнародних організаціях; 3) можливі негативні правові наслідки зовнішніх політичних рішень; 4) недостатність правових та інституційних гарантій захисту інтересів держави та ії суб'єктів у міжнародних правових інстанціях; 5) відсутність моніторингу за виконанням міжнародних зобов' язань держави. Внутрішні загрози правовій безпеці держави стосуються всіх існуючих у правовій системі прогалин, неточностей, внутрішніх суперечностей, неповноцінної функціональної та інституційної дієздатності інститутів влади. Г. Арутунян переконаний, що основною внутрішньою загрозою правовій безпеці держави є дефіцит конституціоналізму, а також непослідовні й нерівноцінні підходи до реалізації принципу верховенства права, відсутність або неповноцінність системного моніторингу правової безпеки [3, с. 13].

В якості загрози правовій безпеці М. Л. Ентін виокремлює інерційність правосвідомості - відсутність розуміння суспільством того, що правова безпека морфологічно нічим не відрізняється від економічної, продовольчої, енергетичної тощо і є однією з складових всеосяжної безпеки держави [4, с. 13]. На переконання А. Єзерова, правова безпека поряд з економічною, інформаційною та іншими видами безпеки, входить до складу національної безпеки [5, с. 122]. Правова безпека розглядається в широкому та вузькому сенсі слова. «У ширшому розумінні вона означає захищеність правової системи, системи права, законодавства в цілому від правових (формально правових - через закріплення в нормах позитивного права) небезпек і загроз, правові засоби забезпечення всіх видів безпеки (національної, державної, економічної, екологічної тощо), у вузькому сенсі - це усунення правових небезпек і загроз як у процесі створення закону, правової норми, так і в процесі правозастосування забезпечення правової безпеки особи, суспільства і держави» [6, с. 63].

Відсутність правової захищеності життєво важливих інтересів держави тягне за собою досить негативні наслідки. Згадаємо, наприклад, як 16.11.1994 р. був прийнятий Закон України «Про приєднання України до Договору про нерозповсюдження ядерної зброї» від 1 липня 1968 р., який відповідно до ст. 6 набрав чинності після надання Україні ядерними державами гарантій безпеки, оформлених шляхом підписання відповідного міжнародно-правового документа [7]. В розділі «Історія документа» на офіційному сайті Верховної Ради України підставою набрання чинності зазначений Меморандум про гарантії безпеки у зв'язку з приєднанням України до Договору про нерозповсюдження ядерної зброї (далі - Меморандум, Будапештський меморандум), а ось позиція «Ратифікація» в історії відсутня. Набрання чинності, відбулось 05.12.1994 [8].

Тут виникає питання, з чого саме було зроблено висновок про надання якісь гарантії? Та що малося на увазі під словом «гарантія»? В інтернет-енциклопедії «Вікіпедія» («Вікіпедія» - тому що це самий поширений ресурс, на якому в самій елементарній формі, доступній навіть народним депутатам, можна знайти роз'яснення незрозумілих термінів) зазначена категорія тлумачиться наступним 
чином: «Юридичні гарантії (фр. garantie - порука, умова, забезпечувати що-небудь) - законодавчо закріплені засоби охорони суб'єктивних прав громадян і організацій, способи їх реалізації, а також засоби забезпечення законності і охорони правопорядку, інтересів особистості, суспільства і держави» [9]. I хоча тут мається на увазі юридична гарантія у внутрішньодержавному праві, можна сміливо виділити головні тези, які, без сумніву актуальні і для права міжнародного. Це: 1) закріплені засоби охорони прав; 2) способи їх реалізації; 3) засоби забезпечення.

На електронному ресурсі «Ліга закон» міжнародні гарантії визначені як норми міжнародно-правових актів, які передбачають охорону прав будь-якої держави або групи держав, забезпечення певного стану міжнародних відносин або виконання договірних зобов'язань. Основною формою міжнародних гарантій є міжнародні договори [10]. Тобто, за логікою та здоровим розсудом у Меморандумі повинні були бути чітко і конкретно прописані зобов'язання сторін щодо забезпечення територіальної цілісності та суверенітету України, в який спосіб вони повинні бути реалізовані, а також умови, процедури створення і діяльності контрольного механізму, а також забезпечення виконання його рішень. Або текст Меморандуму повинен був містити клаузулу про обов'язкову юрисдикцію Міжнародного Суду ООН (арбітражне застереження, в якій держава-учасниця заздалегідь зобов'язується визнати юрисдикцію Суду ООН у разі виникнення спору з іншою державою-учасником щодо тлумачення або застосування договору в майбутньому). Замість останнього, наприклад, сторони зафіксували, що вони «будуть проводити консультації у випадку виникнення ситуації, внаслідок якої постає питання стосовно цих зобов' язань» [11]. Не хочеться навіть критикувати зазначену фразу та аналізувати смислове навантаження, що вона містить.

Тепер розглянемо, які зобов'язання містить міжнародний договір під назвою «Меморандум про гарантії безпеки у зв'язку з приєднанням України до Договору про нерозповсюдження ядерної зброї». Відповідно до тексту Меморандуму, Російська Федерація, Сполучене Королівство Великої Британії та Північної Ірландії і Сполучені Штати Америки підтверджують Україні їх зобов'язання згідно з принципами Заключного акту НБСС поважати незалежність і суверенітет та існуючі кордони України; підтверджують їх зобов'язання утримуватися від загрози силою чи ії використання проти територіальної цілісності чи політичної незалежності; підтверджують Україні їх зобов'язання згідно з принципами Заключного акту НБСЕ утримуватись від економічного тиску, спрямованого на те, щоб підкорити своїм власним інтересам здійснення Україною прав, притаманних їі суверенітету, і таким чином отримати будь-які переваги та підтверджують їх зобов'язання домагатися негайних дій з боку Ради Безпеки ООН з метою надання допомоги Україні як державі-учасниці Договору про нерозповсюдження ядерної зброї, що не володіє ядерною зброєю, в разі, якщо Україна стане жертвою акту агресії або об‘єктом погрози агресією з використанням ядерної зброї [11].

Тобто фактично, контрагенти України підтвердили свої зобов'язання за іншими міжнародними договорами, не взявши на себе жодних об'єктивних зобов'язань перед Україною у зв'язку з приєднанням їі до Договору про нерозповсюдження ядерної зброї. Тут треба наголосити, що це не просте приєднання до багатостороннього договору, на справді, Україна взяла на себе величезні зобов'язання - зробити себе беззахисною в обмін на примарні обіцянки, що все буде добре, а якщо не буде добре, то сторони будуть проводити консультації. Навіть виникає здивування у настільки формальному відношенні сторін, а особливо України до міжнародної угоди, що регулює настільки важливі питання. Пропоную для прикладу проаналізувати передостанній, 5-й пункт Меморандуму, згідно з яким сторони підтверджують щодо України їх зобов'язання не застосовувати ядерну зброю проти будъ-якої (вид. мною - К. В.) держави-учасниці Договору про нерозповсюдження ядерної зброї, що не володіє ядерною зброєю, крім випадку нападу на них самих, їхні території чи їхні підопічні території, їхні збройні сили або на їхніх союзників з боку такої держави спільно або в союзі $з$ державою, яка володіє ядерною зброєю [11]. Як бачимо, сторони підтвердили свої зобов' язання не застосовувати ядерну зброю проти будь-якої держави-учасниці Договору про нерозповсюдження ядерної зброї. А як щодо України і що ж президент Кучма підписав 5 грудня 1994 р. і які гарантії він роздивився в Будапештському меморандумі?

У Віденській конвенції про право міжнародних договорів 1969 р., що є кодифікованим договором про міжнародні договори, немає положень, що стосуються засобів забезпечення договорів. 3 урахуванням відповідної практики держав О. І. Тіунов робить наступне визначення даної категорії: це спеціальні заходи юридичного характеру, що вживаються державами з метою найбільш ефективного виконання взятих міжнародно-правових зобов язань [12, с. 85]. Об‘ єктом спеціальних заходів щодо забезпечення взятих державою зобов'язань є перш за все регулювання відносин на основі міжнародного договору, який являє собою найбільш поширений в даний час джерело міжнародного права. 3 його допомогою держави можуть на узгодженій основі повно і точно висловити свої наміри щодо захисту певного міжнародно-правового зобов'язання. В силу цього міжнародний договір - головна форма 
реалізації заходів щодо забезпечення взятих зобов'язань [12, с. 85]. Таким чином, міжнародно-правовим засобом реалізації договорів і угод є узгоджена державами і закріплена ними за допомогою норм міжнародного права система заходів, спрямована на ефективне виконання міжнародних зобов' язань $[12$, c. 86$]$.

O. I. Тіунов дає наступне визначення міжнародно-правових гарантій. Це особливий юридичний режим, в рамках якого держави-гаранти на основі міжнародно-правового договору (основного або додаткового) беруть на себе зобов'язання і відповідальність за забезпечення дій або утримання від дій певної держави за допомогою прийняття реальних заходів (індивідуально, взаємно або колективно) щодо захисту встановлених договором прав і зобов'язань держави, якій надано гарантія 3 метою встановленого правила поведінки або правового статусу, визначеного положення речей з урахуванням принципів поваги суверенітету, невтручання у внутрішні справи та інших основних принципів міжнародного права [12, с. 89-90].

Гарантії необхідно розглядати і як спосіб забезпечення міжнародних договорів, і як засіб ефективної реалізації міжнародно-правових положень, пов'язаних з основними принципами міжнародного права. Тому об‘єктом гарантії може бути забезпечення: безпеки держави, ії територіальної цілісності і недоторканності; певного статусу держави, наприклад постійного нейтралітету; певного стану речей; певної дії або бездіяльності держави відповідно до взятих зобов'язаннями [12, с. 93]. А. Н. Талалаєв міжнародну гарантію вважає актом, в якому держава або держави зобов'язуються в разі необхідності зробити все від них залежне, щоб спонукати іншу державу або держави виконати укладений між ними договір [13, с. 113].

На думку В. Г. Буткевича, під міжнародно-правовими гарантіями в широкому сенсі розуміють наявність таких складових: основоположні (імперативні) елементи забезпечення нормального функціонування світового співтовариства; ефективна реалізація певних принципів (bona fide, pacta sunt ser vanda, загальних принципів права); функціонування системи органів і організацій ООН; стан міжнародно-економічного співробітництва, що відповідає інтересам усіх членів світового співтовариства; взаємозалежність (факт взаємозалежності держав у забезпеченні їх існування та розвитку). Міжнародно-правові гарантії у вузькому сенсі розуміють як засоби кращого забезпечення реалізації (дотримання) права. Міжнародно-правове значення гарантій полягає у зобов' язаннях за міжнародним правом, згідно з якими одна або кілька держав беруть на себе відповідальність за такими зобов'язаннями перед третьою державою. Не можуть вважатися міжнародно-правовими гарантіями прості домовленості $[14$, с. 611]. I саме в цьому міститься головне питання - чим є Меморандум - простою (політичною) домовленістю або міжнародним договором?

Існують заперечення, що Меморандум є міжнародним договором. І. Лоссовський стверджує: Будапештський меморандум є повноцінним юридично зобов' язальним міжнародним договором, обов'язковим для неухильного виконання всіма його сторонами [15, с. 120]. Так, Україна ого виконала в повному обсязі, віддавши ядерну зброю і обравши для себе роль аутсайдера в зовнішній політиці [16, с. 324]. На 1 червня 1996 р. Україна завершила процес вивезення зі своєї території ядерних боєприпасів. Таким чином, Україна втратила ще й стратегічні засоби стримування проти застосування щодо неї військової сили, що в епоху глобалізації продовжує бути засобом вирішення територіальних суперечок [17, с. 174-181]. А надії на Меморандум про гарантії безпеки у зв'язку 3 приєднанням України до Договору про нерозповсюдження ядерної зброї не мали реального підкріплення, внаслідок чого Україна втратила частину території, отримала проблеми 3 тероризмом та його фінансуванням [18, с. 37-44].

На жаль, Будапештський Меморандум не передбачав конкретного механізму реалізації цих зобов' язань, крім консультацій, не був підкріплений достатніми міжнародно-правовими гарантіями незалежності і суверенітету без'ядерної України. А тому з'явилось звернення Верховної Ради України до Парламенту Сполученого Королівства Великої Британії та Північної Ірландії, Конгресу Сполучених Штатів Америки, Федеральних Зборів Російської Федерації, Парламенту Французької Республіки, Всекитайських Зборів Народних Представників як законодавчих органів країн - гарантів нашої національної безпеки із закликом підтримати цю ініціативу сприятиме зміцненню миру і міжнародної безпеки [19]. Але якщо сама Україна проігнорувала свої інтереси, очікувати, що це зроблять за неї підстави відсутні. Мождиво, саме тому при підписанні Меморандуму на відсутність взагалі будь-яких гарантій або зобов' язань всіх інших підписантів крім України, якщо їі все влаштовувало, увагу не звернули. I пізніші намагання їх отримати post factum були проігноровані: як пише В. Н. Денисов, реакція ядерних держав щодо надання Україні юридичних гарантій безпеки виявилася стриманою [20, с. 324].

Висновки. Меморандум про гарантії безпеки у зв' язку з приєднанням України до Договору про нерозповсюдження ядерної зброї є повноцінним міжнародним договором, положення якого не відповідають інтересам держави. 
В міжнародному праві правова безпека держави є станом, в якому вона має можливість правовими засобами забезпечити визнання своїх прав та зобов'язань інших суб'єктів щодо неї, усунути їх порушення і з допомогою міжнародно-правових механізмів відновити стан, який існував до такого порушення.

Досягнення цього стану повинно забезпечуватись системою міжнародно-правових норм, що встановлюють баланс інтересів держави і міжнародного співтовариства. Зокрема, міжнародними договорами, в яких чітко і конкретно прописані зобов' язання сторін та спосіб їх виконання, що не можуть протирічити інтересам держави, механізми вирішення спорів та процедури відновлення порушених прав.

1. Тимченко Л. Д., Кононенко В. П. Міжнародне право : підручник. К.: Знання, 2012. 631 с.

2. Про національну безпеку України : Закон України від 21 черв. 2018 р.

№ 2469-VIII. URL: https:/ / zakon.rada.gov.ua/laws/ show/2469-19\#Text (дата звернення 22.09.2020).

3. Арутунян Г. Г. Правовая безопасность страны в призме системного конституционного мониторинга. Журнал конституциионного правосудия. 2017. № 5. С. 12-14.

4. Ентин М. Л., Ентина Е. Г., Торкунова Е. А. Современные требования к национальной правовой системе. Журнал зарубежного законодательства и сравнительного правоведения. 2019. № 2. С. 11-23.

5. Сзеров А. А. Конституційна безпека як складник національної безпеки України. Стратегічні nріоритети. 2013. № 2. С. 120-126.

6. Єзеров А. Конституційна безпека як складник національної безпеки України. Украӥнський часопис конституиійного права. 2/2017 (3). С. 60-67.

7. Про приєднання України до Договору про нерозповсюдження ядерної зброї : Закон України від 1 лип. 1968 р. N 248/94-BP. URL: https://zakon.rada.gov.ua/laws/show/248/94-\%D0\%B2\%D1\%80\#Text (дата звернення 22.09.2020).

8. Про приєднання України до Договору про нерозповсюдження ядерної зброї : Закон України від 1 лип. 1968 p. N 248/94-BP. Історія. URL: https://zakon.rada.gov.ua/laws/show/248/94\% D0\% B2\% D1\% 80/card4\#History (дата звернення 18.09.2020).

9. Інтернет-енциклопедія «Вікіпедія» URL: [https://uk.wikipedia.org/wiki/\%D0\% AE\%D1\%80\%D0\% B8\%D0\%B4\%D0\%B8\%D1\%87\%D0\%BD\%D1\%96_\%D0\%B3\%D0\%B0\%D1\%80\%D0\%B0\%D0\%BD \% D1\%82\% D1\%96\% D1\%97 (дата звернення 18.09.2020).

10. Електронний ресурс «Ліга закон» URL: https:/ / ips.ligazakon.net/document/view/TS001340 (дата звернення 18.09.2020).

11. Меморандум про гарантії безпеки у зв'язку з приєднанням України до Договору про нерозповсюдження ядерної зброї URL: https:/ / zakon.rada.gov.ua/laws/show/998_158\#Tехt (дата звернення 18.09.2020).

12. Тиунов О. И. Международно-правовые гарантии как средство обеспечения международных договоров. Журнал российского права. 2011. № 4. С. 85-95.

13. Талалаев А. Н. Право международных договоров: действие и применение договоров. М.: Междунар. отн., 1985. 296 с.

14. Буткевич В. Г. Гарантії міжнародно-правові // Енциклопедія міжнародного права у 3 т. / редкол.: Ю. С. Шемшученко, В. Н. Денисов (співголови) та ін.; Ін ститут держави і права ім. В. М. Корецького НАН України. - Т. 1. А-Д. К.: Академ. періодика, 2014. С. 611-614.

15. Лоссовський I. Міжнародно-правовий статус Будапештського меморандуму: договір, обов' язковий для виконання всіма його сторонами Монографія. К.: Українська асоціація зовнішньої політики, 2015. 124 с.

16. Кононенко В. П. Вирішення територіальних спорів Міжнародним Судом ООН: теорія і практика: монографія. Київ-Одеса: «Фенікс», 2018. 438 с.

17. Кононенко В., Новікова Л. Збройні конфлікти як засіб вирішення територіальних спорів в епоху глобалізації. Публічне право. 2016.

№ 2. C. 174-181.

18. Кононенко В. П., Новікова Л. В. Практика міжнародних судів та міжнародних організацій із протидії фінансуванню тероризму. Альманах міжнародного права. 2015. № 10. С. 37-44.

19. Пояснювальна записка до проекту Постанови про Заяву Верховної Ради України: „Без“ядерному статусу України-реальнігарантії“ URL:http:/ / w1.c1.rada.gov.ua/pls/zweb2/webproc4_1?pf3511=36444 (дата звернення 21.09.2020).

20. Денисов В. Н. Будапештський меморандум // Енциклопедія міжнародного права у 3 т. / редкол.: Ю. С. Шемшученко, В. Н. Денисов (співголови) та ін., ; Ін ститут держави і права ім. В. М. Корецького НАН України. - Т. 1. А-Д. - К. : Академ. періодика, 2014. С. 322-324. 


\section{Summary}

The legal security of the state is a state. In this state, it has the opportunity by legal means to ensure the recognition of its rights and obligations of other entities to it. And also to eliminate their violations and with the help of international legal mechanisms to restore the state that existed before such a violation.

Achieving this state must be ensured by a system of international law. These norms establish a balance of interests of the state and the international community. In particular, international agreements, which clearly and specifically specify the obligations of the parties and the manner of their implementation. As well as dispute resolution mechanisms and procedures for restoring violated rights. They can not contradict the interests of the state.

The lack of legal protection of vital interests of the state entails quite negative consequences. The Memorandum of Security Guarantees in connection with Ukraine's accession to the Treaty on the NonProliferation of Nuclear Weapons should have clearly and specifically stated the obligations of the parties to ensure the territorial integrity and sovereignty of Ukraine. Also, the method of implementation of these obligations and conditions, procedures for the establishment and operation of the control mechanism. And ensuring the implementation of its decisions. Or the text of the Memorandum should have contained a clause on the mandatory jurisdiction of the International Court of Justice.

International legal guarantees are a special legal regime under which the guarantor states undertake obligations on the basis of an international legal agreement (basic or additional). Specifically, the responsibility for ensuring the actions or refraining from the actions of a particular state by taking real measures (individually, mutually or collectively) to protect the rights and obligations of the state, which is guaranteed. In order to ensure an established rule of conduct or legal status, a certain state of affairs, taking into account the principles of respect for sovereignty, non-interference in internal affairs and other basic principles of international law.

Guarantees must be seen both as a way of securing international treaties and as a means of effectively implementing international legal provisions related to the basic principles of international law. Therefore, the object of the guarantee may be to ensure: security of the state, its territorial integrity and inviolability; a certain status of the state, such as permanent neutrality; a certain state of affairs; certain action or inaction of the state in accordance with the commitments.

Unfortunately, the Budapest Memorandum did not provide for a specific mechanism for implementing these commitments, apart from consultations, and was not supported by sufficient international legal guarantees of the independence and sovereignty of nuclear-free Ukraine. That is why the Verkhovna Rada of Ukraine appealed to the Parliament of the United Kingdom of Great Britain and Northern Ireland, the Congress of the United States of America, the Federal Assembly of the Russian Federation, the Parliament of the French Republic, the All-China Assembly of People's Representatives as legislators. the initiative will promote peace and international security. But if Ukraine itself has ignored its interests, there is no reason to expect it to do so. Perhaps that is why the signing of the Memorandum did not pay attention to the absence of any guarantees or obligations of all other signatories except Ukraine, if everything suited it. And later attempts to obtain them post factum were ignored. As writes V. Denisov, the reaction of the nuclear powers to provide Ukraine with legal security guarantees was restrained. 